\title{
Rapid, Labile, and Protein Synthesis- Independent Short-Term Memory in Conditioned Taste Aversion
}

\author{
E.W. Bourne Behavioral Research Laboratory \\ Department of Psychiatry \\ Cornell University Medical College \\ White Plains, New York 10605 USA
}

Thomas A. Houpt ${ }^{1,2}$ and RoseAnn Berlin

\begin{abstract}
Short-term memory is a rapid, labile, and protein-synthesis-independent phase of memory. The existence of short-term memory in conditioned taste aversion (CTA) learning has not been demonstrated formally. To determine the earliest time at which a CTA is expressed, we measured intraoral intake of sucrose at $15 \mathrm{~min}, 1 \mathrm{hr}, 6$ $\mathrm{hr}$, or $48 \mathrm{~h}$ after contingent pairing of an intraoral infusion of $5 \%$ sucrose $(6.6 \mathrm{ml}$ over $6 \mathrm{~min}$ ) and toxic lithium chloride injection $(76 \mathrm{mg} / \mathrm{kg})$. Rats were implanted with intraoral catheters to allow presentation of taste solutions at arbitrary times. Intraoral intake was measured under conditions of long-delay, single-trial learning typical of CTA. Rats decreased intraoral intake of sucrose at 15 min after contingent pairing of sucrose and LiCl, but not after noncontingent $\mathrm{LiCl}$ or sucrose. Thus CTA learning can be expressed rapidly. To determine if short-term CTA memory is labile and decays in the absence of long-term memory, we measured intraoral intake of sucrose after pairing sucrose with low doses of LiCl. Rats received an intraoral infusion of $5 \%$ sucrose ( $6 \mathrm{ml} / 6 \mathrm{~min}) ; 30$ min later LiCl was injected at three different doses $(19,38$, or $76 \mathrm{mg} / \mathrm{kg})$. A second intraoral infusion of sucrose was administered $15 \mathrm{~min}, 1 \mathrm{hr}, 3 \mathrm{hr}, 4.5 \mathrm{hr}, 6 \mathrm{hr}$, or $48 \mathrm{hr}$ later. The formation of long-term
\end{abstract}

\footnotetext{
${ }^{1}$ Present address: Department of Biological Science, The Florida State University, Tallahassee, Florida 32306-4340 USA.

${ }^{2}$ Corresponding author.
}

CTA memory was dependent on the dose of LiCl paired with sucrose during acquisition. Low doses of LiCl induced a CTA that decayed within $6 \mathrm{hr}$ after pairing. Central administration of the protein synthesis inhibitor cycloheximide prior to $\mathrm{LiCl}$ injection blocked long-term CTA expression at 6 and $48 \mathrm{hr}$, but not short-term CTA expression at $1 \mathrm{hr}$. Thus, short-term memory for CTA learning exists that is acquired rapidly and independent of protein synthesis, but labile in the absence of long-term memory formation.

\section{Introduction}

Conditioned taste aversion (CTA) is a form of associative learning in which an animal avoids the taste of a food previously paired with toxic effects. CTA has a number of unique temporal properties that distinguish it from other forms of learning and memory. Unlike most other forms of learning, CTA learning is single-trial, long-delay, and persistent. Rather than requiring multiple acquisition trials, a robust CTA can be acquired after a single pairing (Garcia and Koelling 1967). CTA can be acquired even when the contingent presentations of taste and toxin are separated by extremely long intervals (up to 12 hr; Garcia et al. 1966; Smith and Roll 1967). CTA learning appears to be optimized for long delays, because simultaneous or short-delay pairing is less effective than long-delay pairing (Schafe et al. 1995). CTAs are also extremely persistent, with little or no loss of memory months after a small number of trials (Houpt et al. 1996). These adaptations of CTA learning to a lengthy time course have been correlated with the need to associate the acute taste of a poisonous food with

LEARNING \& MEMORY 6:37-46 @ 1999 by Cold Spring Harbor Laboratory Press ISSN1072-0502/99 \$5.00

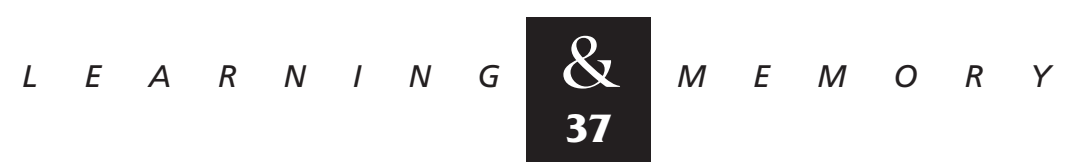


toxic events that may be life threatening, but occur hours after ingestion (Garcia and Ervin 1968).

Because the prolonged nature of CTA learning distinguishes it from other forms of learning, most research has focused on the long time course of CTA memory (days to months after pairing taste and toxin). There have been few studies of CTA memory in the short-term (minutes to hours after pairing). The existence of short-term memory in other forms of learning is well established, but a short-term memory phase has never been demonstrated formally in CTA learning.

If a learned behavior has a short-term memory phase, it must meet at least three criteria: 1) it should be acquired rapidly and expressed within minutes; 2) it should be labile and forgotten rapidly within minutes to hours under some conditions; and 3) it should be expressed in the absence of protein synthesis prior to long-term consolidation. In this study we demonstrate that CTA learning in rats has a short-term memory phase that meets these three criteria.

We employed a CTA paradigm in which a palatable, sweet taste ( $5 \%$ sucrose) was paired with toxic injections of lithium chloride $30 \mathrm{~min}$ after presentation of the taste solution (Houpt et al. 1994). Because we used this paradigm, the shortterm time course of CTA expression was tested under conditions that (1) support long-delay learning; (2) mediate long-term taste aversions (e.g., up to 6 months after three pairings; Houpt et al. 1996); and (3) use intake as the behavioral measure of CTA expression.

Rats were outfitted with chronic intraoral catheters. Intraoral infusions of the taste stimulus were employed because this allows a standard orosensory stimulus to be presented to all rats regardless of deprivation state or somatic behavioral response. This makes the test of CTA expression more analogous to other learning paradigms, in which a standard stimulus is presented both before and after conditioning (e.g., the tone paired with shock in fear conditioning). Intraoral infusions have proven to be a very sensitive measure of CTA expression that parallels the independent ingestive responses measured by ad lib bottle intake (Grill and Berridge 1985). In ad lib bottle tests, however, the rat is not presented with a standard and controlled stimulus, because presentation of the stimulus from the bottle is confounded by competing somatic behaviors. For example, expression of the transient "lying-on-belly" behavior induced by acute $\mathrm{LiCl}$ injection is incompatible with ad lib drinking from a bottle. Intraoral infusions avoid this confound: Rats can consume (or reject) an intraoral infusion even when expressing competing behaviors such as rearing, grooming, etc.

Rats were infused intraorally with 5\% sucrose at arbitrary times after pairing with LiCl. Intake was measured by weighing the rats immediately before and after the intraoral infusions. The expression of the CTA was followed over time by giving the rats a standard intraoral infusion of sucrose between 15 min and $48 \mathrm{hrs}$ after pairing. CTA acquisition was found to be rapid, because a CTA was expressed within $15 \mathrm{~min}$.

In addition, the dose of $\mathrm{LiCl}$ paired with intraoral infusions of sucrose was varied to determine if the short-term expression and long-term consolidation of a CTA could be dissociated. In fact, CTA memory was found to be labile at lower doses of LiCl, but long lasting at the highest dose employed. Finally, administration of the protein synthesis inhibitor cycloheximide between the intraoral infusion of sucrose and the injection of $\mathrm{LiCl}$ did not attenuate short-term CTA expression but blocked long-term CTA expression completely. Thus, the short-term expression of a CTA is also protein synthesis independent.

\section{Materials and Methods}

\section{CHRONIC INTRAORAL CATHETERS}

Adult male Sprague-Dawley rats (300-400 grams) were used in all experiments. Rats were housed individually under a 12:12 light/dark cycle at $25^{\circ} \mathrm{C}$, with ad lib access to rodent chow and water except as noted below. All experimental procedures began in the first half of the lights-on period.

Anterior sublingual intraoral catheters were implanted under methoxyflurane anesthesia as described previously (Houpt et al. 1994). Intraoral catheters were prepared from $10 \mathrm{~cm}$ of PE-50 polyethylene tubing; one end of the catheter was heatflared to form a 2-mm-diam. annular end. A small incision was made on the ventral midline between the mandibles, and a bent 23-gauge syringe needle pushed between the mandibles until the needle projected into the mouth midway between the root of the lower incisors and the base of the tongue. The unflared end of the catheter was affixed to the end of the syringe needle; the needle was retracted to pull the tubing along the needle tract and out the incision on the ventral submental

$$
\begin{array}{llllllllllllllll} 
& E & A & R & N & I & N & G & \begin{array}{l}
\boldsymbol{Q} \\
38
\end{array} & M & E & M & O & R & Y
\end{array}
$$


surface until the flared end of the catheter rested on the floor of the mouth beneath the tongue.

An incision was then made from the caudal extent of the skull to midway between the scapulas on the dorsal surface of the rat's neck. A blunt wire probe was threaded between the skin and the musculature from the dorsal incision to the ventral submental incision. Then the end of the intraoral catheter was attached to the wire probe, which was pulled back with the intraoral catheter under the skin and externalized through the dorsal incision. The intraoral catheter was held in place by threading it through an outer sleeve of 0.040 silastic tubing attached to a 15-mm diameter Marlex mesh disk (Bard-Parker, Billerica, MA) sutured to the dorsal neck musculature. A 5-cm length of sleeve and catheter projected from the dorsal surface of the rat for attachment to an infusion catheter. The neck incision was closed with wound clips on either side of the catheter sleeve and the submental incision was sutured closed. Rats were tested 4 days after surgery.

Rats were tested in a glass aquarium separated into subchambers by plexiglas dividers, so that four rats could be tested at the same time. During intraoral infusions, syringe pumps (Harvard Apparatus) infused 5\% sucrose from $20 \mathrm{ml}$ syringes at a rate of $1.1 \mathrm{ml} / \mathrm{min}$ for $6 \mathrm{~min}$ through PE-50 tubing attached to the externalized end of the implanted intraoral catheters. Rats were weighed immediately before and after each infusion (along with all feces produced during the infusion) as a measure of intraoral intake during the infusion. Intraoral catheters were flushed with distilled water after each intraoral infusion of sucrose, and the rats returned to their home cages.

\section{EXPERIMENT 1: RAPID EXPRESSION OF CTA LEARNING}

Rats with intraoral catheters were divided into three groups: A contingent group ( $n=30)$, a noncontingent $\mathrm{LiCl}$ group $(n=24)$, and a noncontingent sucrose group ( $n=25)$. The contingent group received a single intraoral infusion of sucrose followed 30 min later by a single toxic $\mathrm{LiCl}$ injection; this protocol supports long-term, long-delay, single-trial acquisition of a CTA against sucrose. The two noncontingent groups controlled for the acute, unconditioned effects of $\mathrm{LiCl}$ and sucrose in the short-term tests. Both noncontingent groups received a single intraoral infusion of sucrose and a single injection of $\mathrm{LiCl}$, but with a 24-hr interval between the taste of sucrose and the toxic effects of $\mathrm{LiCl}$. The noncontingent $\mathrm{LiCl}$ group controlled for any short-term effects of $\mathrm{LiCl}$ toxicosis on intraoral intake of sucrose. The noncontingent sucrose group controlled for any short-term effects of sucrose intake on subsequent intraoral intake of sucrose. These noncontingent groups were not expected to acquire a long-term CTA.

Rats in the contingent group were deprived of food overnight for $17 \mathrm{hr}$. They received an intraoral infusion of $5 \%$ sucrose $(6.6 \mathrm{ml}$ over $6 \mathrm{~min})$. Intake was measured by weighing as described above, and the intraoral catheters were flushed after the infusion with distilled water. Thirty minutes after the start of the intraoral infusion, the rats were injected with $\mathrm{LiCl}(0.15 \mathrm{M}, 76 \mathrm{mg} / 12 \mathrm{ml}$ per $\mathrm{kg}$, i.p.). Individual rats were then infused with a second intraoral infusion of $5 \%$ sucrose $(6.6 \mathrm{ml}$ over $6 \mathrm{~min}$ ) at either $15 \mathrm{~min}, 1 \mathrm{hr}, 6 \mathrm{hr}$, or $48 \mathrm{hr}$ after the $\mathrm{LiCl}$ injection. Intake was measured by weighing the rats before and after the infusion. Rats receiving their second intraoral infusion at 15 min, $1 \mathrm{hr}$, or $6 \mathrm{hr}$ had access to water, but not food, before their second intraoral infusion. Rats receiving their second intraoral infusion at $48 \mathrm{hr}$ were refed $1 \mathrm{hr}$ after the $\mathrm{LiCl}$ injection, and deprived of food for $17 \mathrm{hr}$ prior to the second intraoral infusion. Each rat was tested at only one time point after $\mathrm{LiCl}$ ( $n=7-9$ at each time point).

Rats in the noncontingent $\mathrm{LiCl}$ group received an intraoral infusion of $5 \%$ sucrose $(6.6 \mathrm{ml}$ over 6 min). Intake was measured by weighing and the intraoral catheters flushed after the infusion with distilled water. They were then deprived of food overnight for $17 \mathrm{hr}$. Twenty-four hours after the intraoral infusion of sucrose, the rats were injected with $\mathrm{LiCl}(76 \mathrm{mg} / 12 \mathrm{ml} / \mathrm{kg}$, i.p.). Thus, the noncontingent $\mathrm{LiCl}$ group received both an intraoral infusion of sucrose and a toxic injection of $\mathrm{LiCl}$ prior to testing, but without contingent pairing because CTA learning does not support a 24-hr delay between taste and toxin. Individual rats in the noncontingent $\mathrm{LiCl}$ group were then infused with a second intraoral infusion of $5 \%$ sucrose $(6.6 \mathrm{ml}$ over $6 \mathrm{~min}$ ) at either $15 \mathrm{~min}, 1 \mathrm{hr}, 6 \mathrm{hr}$, or $48 \mathrm{hr}$ after the $\mathrm{LiCl}$ injection as described for the contingent group ( $n=4-8$ at each time point).

Rats in the noncontingent sucrose group were injected with $\mathrm{LiCl}$ (76 mg/12 ml/kg, i.p.) They were then deprived of food overnight for $17 \mathrm{hr}$. Twenty-four hours after the $\mathrm{LiCl}$ injection the rats received an intraoral infusion of 5\% sucrose $(6.6 \mathrm{ml}$ over $6 \mathrm{~min})$. Intake was measured by weighing and

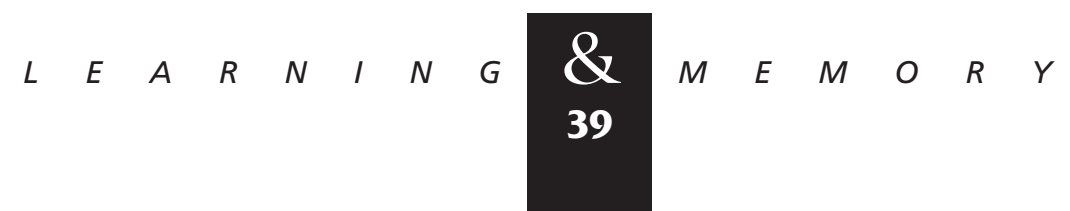


the intraoral catheters flushed after the infusion with distilled water. Thus the noncontingent sucrose group received both a toxic injection of $\mathrm{LiCl}$ and an intraoral infusion of sucrose prior to testing, but without contingent pairing because CTA learning does not support a 24-hr delay between toxin and taste. Individual rats in the noncontingent sucrose group were then infused with a second intraoral infusion of $5 \%$ sucrose $(6.6 \mathrm{ml}$ over $6 \mathrm{~min})$ at either $15 \mathrm{~min}, 1 \mathrm{hr}, 6 \mathrm{hr}$, or $48 \mathrm{hr}$ after the $\mathrm{LiCl}$ injection as described for the contingent and noncontingent LiCl group ( $n=5-8$ at each time point).

Intakes during the second intraoral infusions were compared by two-way ANOVA with group and time as factors; post-hoc comparisons were made with Fisher's PLSD. To determine the unconditioned effects of the different treatments at the earliest time point, intakes during the first intraoral infusion and intakes during the second test intraoral infusion were compared within each group at the 15 -min time point by paired $t$-test.

\section{EXPERIMENT 2: LABILE EXPRESSION OF CTA LEARNING}

Rats acquire CTAs readily when a taste is paired with $\mathrm{LiCl}$; the effects of $\mathrm{LiCl}$ on CTA acquisition, however, are dose-dependent (Nachman and Ashe 1973). If CTA learning has both shortterm and long-term phases of memory, then acquisition of a short-term CTA may occur after both lower and higher doses of $\mathrm{LiCl}$, whereas consolidation of long-term memory may occur only after higher doses of $\mathrm{LiCl}$. To test this possibility, we constructed a $\mathrm{LiCl}$ dose-response curve for shortterm expression of a CTA. Rats were tested for CTA expression against intraoral infusions of sucrose at different time points from $15 \mathrm{~min}$ to $48 \mathrm{hr}$ after pairing an intraoral infusion of sucrose with varying doses of $\mathrm{LiCl}$.

Rats $(n=90)$ were deprived of food overnight for $17 \mathrm{hr}$. They received an intraoral infusion of 5\% sucrose ( $6.6 \mathrm{ml}$ over $6 \mathrm{~min})$. Intake was measured as described above by weighing, and the intraoral catheters were flushed after the infusion with distilled water. Thirty minutes after the start of the intraoral infusion, the rats were injected with isotonic $\mathrm{NaCl}(12 \mathrm{ml} / \mathrm{kg}$ i.p.) or $\mathrm{LiCl}$ at three different doses $(19,38$, or $76 \mathrm{mg} / 12 \mathrm{ml} / \mathrm{kg}$, i.p., made isotonic with $\mathrm{NaCl}$ ). Individual rats were then infused with a second intraoral infusion of 5\% sucrose (6.6 $\mathrm{ml}$ over $6 \mathrm{~min}$ ) at $15 \mathrm{~min}, 1 \mathrm{hr}, 6 \mathrm{hr}, 3 \mathrm{hr}, 4.5 \mathrm{hr}$, or $48 \mathrm{hr}$ after the $\mathrm{LiCl}$ injection. Intake was mea- sured by weighing the rats before and after the infusion. Rats receiving their second intraoral infusion at $15 \mathrm{~min}, 1 \mathrm{hr}$, or $6 \mathrm{hr}$ had access to water but not food before their second intraoral infusion. Rats receiving their second intraoral infusion at 48 $\mathrm{hr}$ were refed $1 \mathrm{hr}$ after the $\mathrm{LiCl}$ injection, and 17-hr food-deprived prior to the second intraoral infusion at $48 \mathrm{hr}$.

The intakes from the contingent group of experiment $1(76 \mathrm{mg} / \mathrm{kg} \mathrm{LiCl}$ at $15 \mathrm{~min}, 1 \mathrm{hr}, 6 \mathrm{hr}$, and $48 \mathrm{hr}$ ) were included in the results of experiment 2 . Additional rats injected with $76 \mathrm{mg} / \mathrm{kg} \mathrm{LiCl}$ were tested at 3 and $4.5 \mathrm{hr}$. Rats injected with $\mathrm{NaCl}$ were tested at $15 \mathrm{~min}, 1 \mathrm{hr}, 6 \mathrm{hr}$, and $48 \mathrm{hr}$. Rats injected at lower doses of $\mathrm{LiCl}$ were tested at all six time points. Each rat was tested at only one time point after $\mathrm{LiCl}$ ( $n=5$ at each time point for each dose).

Intakes during the intraoral infusions were compared by two-way ANOVA with LiCl dose and time as factors; post-hoc comparisons were made with Fisher's PLSD.

\section{EXPERIMENT 3: PROTEIN SYNTHESIS-INDEPENDENT CTA LEARNING}

A widely accepted, mechanistic definition of short-term memory is that short-term memory can be expressed in the absence of protein synthesis, whereas long-term memory requires protein synthesis. Using this definition, short-term memory can be distinguished from long-term memory by demonstrating that a short-term memory can be expressed even after protein synthesis is inhibited during learning, while long-term memory is attenuated or blocked. To determine the role of protein synthesis in CTA learning, rats were tested for CTA expression against intraoral infusions of sucrose at different time points after pairing an intraoral infusion of sucrose with $\mathrm{LiCl}$ after central administration of cycloheximide. We used a dose of cycloheximide $(250 \mu \mathrm{g} / 10 \mu \mathrm{l})$ that has been demonstrated previously to attenuate CTA learning in rats when administered intracerebroventricularly (ICV) (Tucker and Gibbs 1979).

Rats were implanted and tested with ICV cannulas as described previously (Houpt et al. 1998). Under chloral hydrate (153 mg/kg)-pentobarbital (35 mg/kg) anesthesia, each rat was implanted stereotaxically with a 22-gauge, stainless-steel, guide cannula (Plastics One, Roanoke, VA) aimed towards the lateral cerebral ventricle $(1.2 \mathrm{~mm}$ caudal to bregma, $1.5 \mathrm{~mm}$ lateral to the midline, and $4 \mathrm{~mm}$

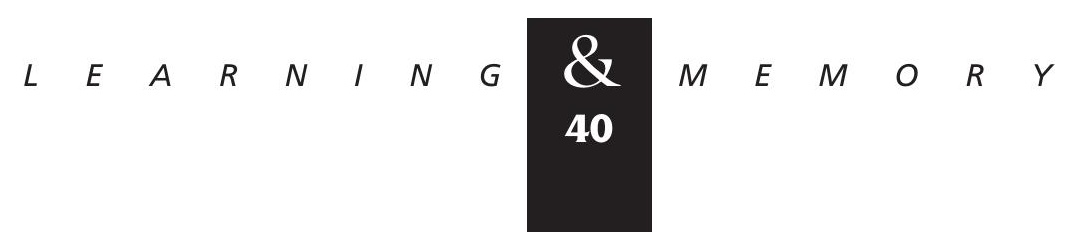


below the skull surface). Guide cannulas were held in place with dental acrylic bonded to stainless steel screws anchored to the skull. An obdurator was inserted into each guide cannula and remained in place except during injections, when it was removed and replaced with an injector that extended $1.0 \mathrm{~mm}$ beyond the tip of the guide cannula. Seven to 10 days after implantation of the ICV cannulas, rats were implanted with intraoral catheters as described above. Patency of the ICV cannulas was tested by measuring intraoral and ad lib intake of water after ICV injection of $100 \mathrm{ng}$ of human angiotensin II (Sigma, St Louis, MO) dissolved in a 5- $\mu$ l volume of $0.15 \mathrm{M} \mathrm{NaCl}$, or $\mathrm{NaCl}$ alone; only rats that drank more water after angiotensin injection than after saline injection were included in the study $(n=33)$.

Rats were deprived of food overnight for 17 hr. They received an intraoral infusion of 5\% sucrose $(6.6 \mathrm{ml}$ over $6 \mathrm{~min})$. Intake was measured as described above by weighing, and the intraoral catheters were flushed after the infusion with distilled water. Fifteen minutes after the start of the intraoral infusion, the rats were injected ICV with 0.15 м NaCl $(10 \mu \mathrm{l})$ or cycloheximide $(250 \mu \mathrm{g} / 10$ $\mu \mathrm{l}$ of $0.15 \mathrm{M} \mathrm{NaCl}$ ). Fifteen minutes after the central injection, all rats were injected with $\mathrm{LiCl}(76 \mathrm{mg} /$ $12 \mathrm{ml} / \mathrm{kg}$, i.p.). Individual rats were then infused with a second intraoral infusion of 5\% sucrose (6.6 $\mathrm{ml}$ over $6 \mathrm{~min}$ ) at 1,6 , or $48 \mathrm{hr}$ after the $\mathrm{LiCl}$ injection ( $n=5-8$ at each time point and drug treatment). Intake was measured by weighing the rats before and after the infusion. Rats receiving their second intraoral infusion at 1 or $6 \mathrm{hr}$ had access to water but not food before their second intraoral infusion. Rats receiving their second intraoral infusion at $48 \mathrm{hr}$ were refed $1 \mathrm{hr}$ after the $\mathrm{LiCl}$ injection and deprived of food for $17 \mathrm{hr}$ prior to the second intraoral infusion at $48 \mathrm{hr}$.

\section{Results}

\section{EXPERIMENT 1: RAPID EXPRESSION}

Contingent pairing of an intraoral infusion of $5 \%$ sucrose with a toxic injection of $\mathrm{LiCl}$ caused rats to reject a second intraoral infusion of sucrose within $15 \mathrm{~min}$ and up to $48 \mathrm{hr}$ later (Fig. 1A). This constitutes expression of a learned CTA, because rats treated noncontingently with either toxic $\mathrm{LiCl}$ injections or intraoral infusions of sucrose did not significantly decrease their intake of sucrose at any time point (Fig. 1B,C). Paired $t$-tests between in- take during the first intraoral infusion and intake during intraoral infusions at $15 \mathrm{~min}$ revealed that intake was decreased significantly only in the contingent group $(P<0.0004)$.

Only the contingent group had significantly lower intakes of 5\% sucrose during their second intraoral infusion compared to their first intraoral infusion of sucrose prior to LiCl injection $(F[1,29]=137.8 ; P<0.0001)$; intakes were significantly lower at all time points after the pairing of sucrose and $\mathrm{LiCl}(P<0.0001)$.

During the second intraoral infusions, intake was affected significantly by treatment $(F[2,67]=79.0, \quad P=0.0001) \quad$ and test time $(F[3,67]=5.3, P<0.005)$, but no interaction was found $(F[6,67]=0.5$, N.S. $)$.

Post-hoc comparisons showed that intakes of the contingent group were significantly lower than intakes of the noncontingent groups at all time points $(P<0.0005)$; the intakes of the noncontingent $\mathrm{LiCl}$ group and the noncontingent sucrose group were not different from each other at any time point.

\section{EXPERIMENT 2: LABILE EXPRESSION}

Pairing an intraoral infusion of 5\% sucrose with $\mathrm{NaCl}$ injections did not cause a decrease in intraoral intake of sucrose at any time point (Fig. 2). After pairing an intraoral infusion of 5\% sucrose with doses of $\mathrm{LiCl}$ ranging from 19 to $76 \mathrm{mg} / \mathrm{kg}$, a CTA was expressed within $15 \mathrm{~min}$ by rejecting a second intraoral infusion (Fig. 2). Intakes during the second intraoral infusions were affected significantly by dose of $\mathrm{LiCl}(F[3,98]=51.1, P=0.0001)$ and the time since the initial pairing $(F[5,98]=9.4$, $P=0.0001)$; a significant interaction was found between dose and time $(F[13,98]=3.0, P<0.005)$. Post hoc comparisons showed that pairing sucrose with any of the three $\mathrm{LiCl}$ doses significantly reduced intake at $15 \mathrm{~min}$ and $1 \mathrm{hr}$ compared to the $\mathrm{NaCl}$ controls $(P<0.0005)$, but only the highest dose of $\mathrm{LiCl}(76 \mathrm{mg} / \mathrm{kg})$ significantly reduced intake at 6 and $48 \mathrm{hr}$ compared to the $\mathrm{NaCl}$ controls $(P<0.0001)$. Thus, after pairing sucrose with doses of LiCl below $76 \mathrm{mg} / \mathrm{kg}$, CTA expression was labile: Rats injected with 19 and $38 \mathrm{mg} / \mathrm{kg} \mathrm{LiCl}$ rejected sucrose during the first $3 \mathrm{hr}$ but consumed volumes of sucrose at 6 and $48 \mathrm{hr}$ that were not significantly different from the intake after saline treatment (Fig. 2).

Whereas there was no significant difference between doses of $\mathrm{LiCl}$ at $15 \mathrm{~min}, 1 \mathrm{hr}$, and $3 \mathrm{hr}$, the

$$
\begin{array}{llllllllllllllll}
L & E & A & R & N & I & N & G & \begin{array}{l}
\boldsymbol{Z} \\
\mathbf{4 1}
\end{array} & M & E & M & O & R & Y
\end{array}
$$



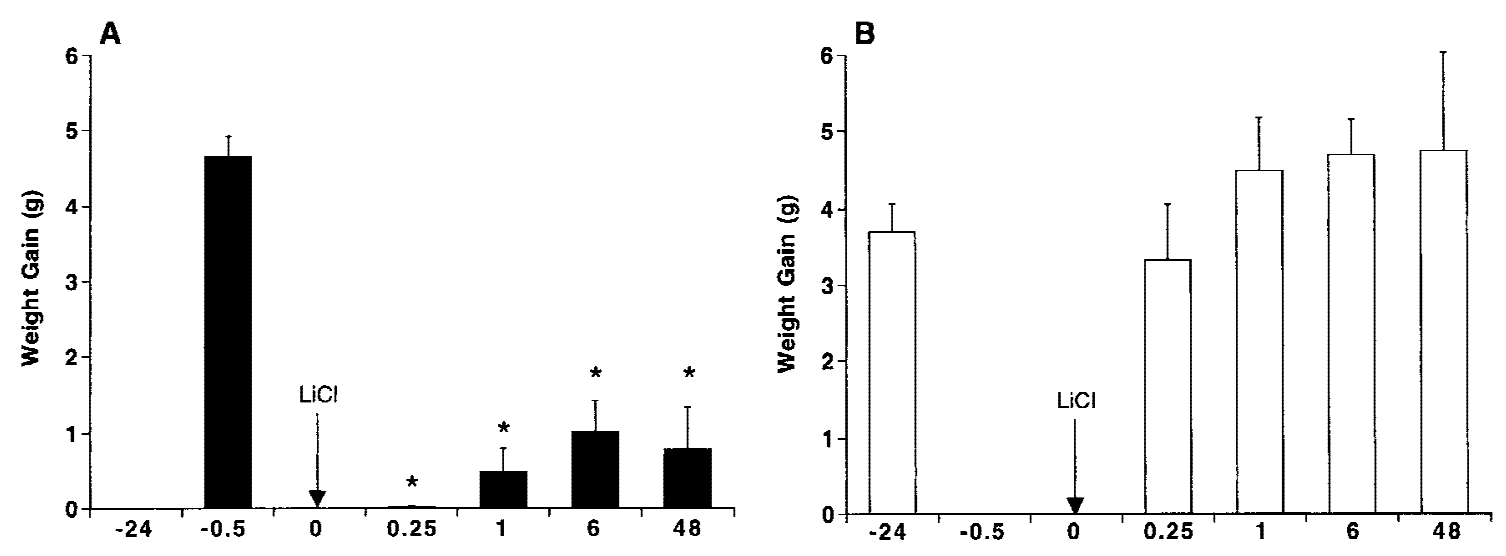

Figure 1: Rapid expression of a CTA. Intraoral intake of 5\% sucrose was measured as weight gain during the intraoral infusion. Individual rats were tested only once at one time point $(n=4-9)$. Arrows indicate the times of $\mathrm{LiCl}$ injection $(76 \mathrm{mg} / 12$ $\mathrm{ml} / \mathrm{kg}$, i.p.). (A) Intraoral intake of $5 \%$ sucrose after contingent pairing of an intraoral infusion of $5 \%$ sucrose $(6.6 \mathrm{ml}$ over $6 \mathrm{~min})$ and $\mathrm{LiCl}$. Rats significantly decreased their intraoral intake of sucrose at 15 min after pairing. $\left({ }^{*}\right) P<0.005$ compared to noncontingent lithium or noncontingent sucrose. $(B)$ Intraoral intake of $5 \%$ sucrose after noncontingent injection of $\mathrm{LiCl}$. Rats received an intraoral infusion of $5 \%$ sucrose $(6.6 \mathrm{ml}$ over $6 \mathrm{~min})$ $24 \mathrm{hr}$ prior to the $\mathrm{LiCl}$ injection. Intraoral intake was not significantly reduced after noncontingent $\mathrm{LiCl}$. (C) Intraoral intake of $5 \%$ sucrose after a noncontingent intraoral infusion of $5 \%$ sucrose $(6.6 \mathrm{ml}$ over $6 \mathrm{~min})$. Rats received an injection of $\mathrm{LiCl} 24$ $\mathrm{hr}$ prior to the intraoral infusion of sucrose. Intraoral intake was not reduced significantly after noncontingent sucrose.

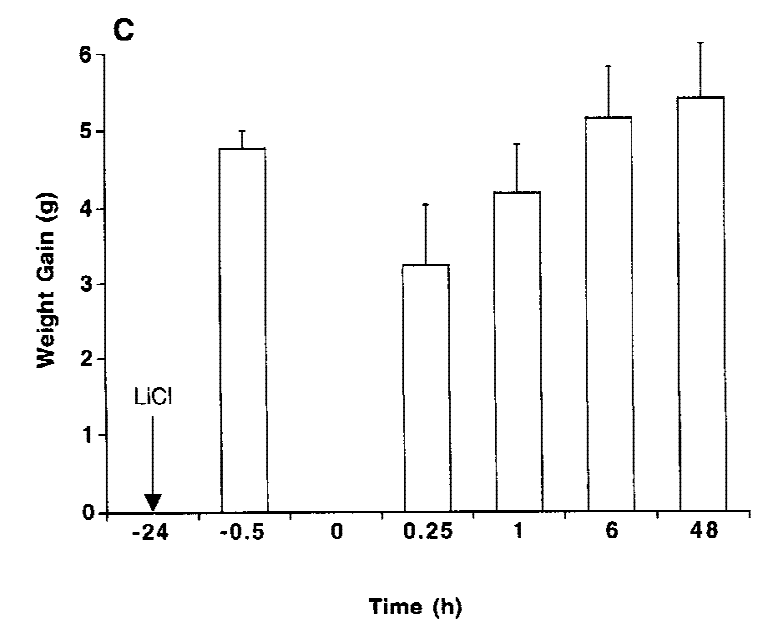

effects of the lower doses began to diverge from the effects of the highest dose after $3 \mathrm{hr}$. At $4.5 \mathrm{hr}$, the intakes of the $19 \mathrm{mg} / \mathrm{kg}$ group were significantly greater than both the 38 and $76 \mathrm{mg} / \mathrm{kg}$ groups $(P<0.05)$. At 6 and $48 \mathrm{hr}$, both 19 and 38 $\mathrm{mg} / \mathrm{kg}$ groups consumed more sucrose than the 76 $\mathrm{mg} / \mathrm{kg}$ group $(P<0.005)$.

\section{EXPERIMENT 3: PROTEIN SYNTHESIS INHIBITION}

Central administration of the protein synthesis inhibitor cycloheximide during pairing of an intraoral infusion of $5 \%$ sucrose with $\mathrm{LiCl}$ did not attenuate CTA expression at $1 \mathrm{hr}$, but significantly attenuated CTA expression at 6 and 48 hr (Fig. 3). Intakes during the second intraoral infusions were affected significantly by cycloheximide treatment $(F[1,31]=28.5, P=0.003)$ and the time since the initial pairing $(F[2,31]=51.8, P=0.0005)$, but no significant interaction was found between cycloheximide treatment and time. Post hoc compari- sons showed ICV cycloheximide significantly increased sucrose intake at 6 and $48 \mathrm{hr}$, but not at 1 hr, compared to $\mathrm{NaCl}$ controls $(P<0.05)$; sucrose intake after cycloheximide injection was not significantly different at 6 and $48 \mathrm{hr}$ from sucrose intake during the initial infusion before LiCl. Thus, after administering cycloheximide within the pairing of sucrose with a high doses of LiCl, short-term CTA expression at $1 \mathrm{hr}$ was unattenuated and thus protein synthesis independent. At later time points (6 and $48 \mathrm{hr}$ ), no significant expression of a CTA expression was found after cycloheximide treatment. Thus, long-term CTA expression requires protein synthesis at the time of contingent pairing of sucrose and $\mathrm{LiCl}$.

\section{Discussion}

Short-term memory is rapid, labile, and protein synthesis independent. CTA learning appears to have a short-term phase of memory that meets these criteria. CTA learning is rapid, because the

$$
\begin{array}{llllllllllllllll}
L & E & A & R & N & I & N & G & \begin{array}{l}
\boldsymbol{Z} \\
\mathbf{4 2}
\end{array} & M & E & M & O & R & Y
\end{array}
$$




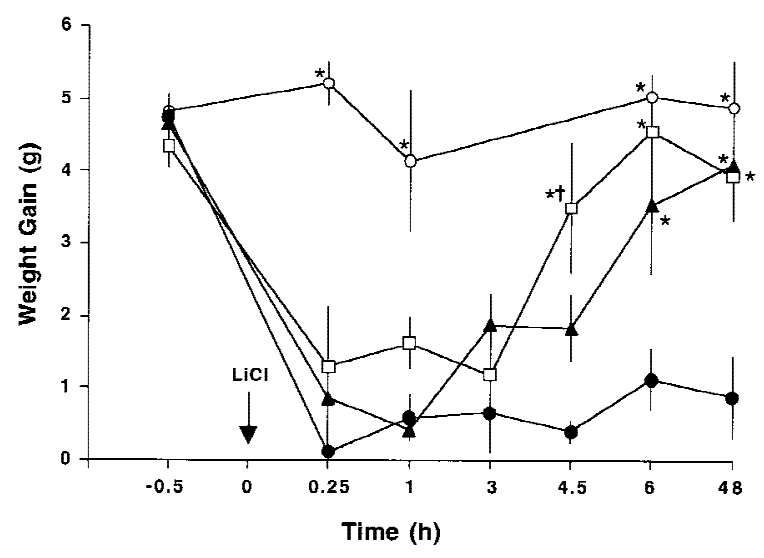

Figure 2: Dose-dependent expression of a labile shortterm CTA. Intraoral intake of $5 \%$ sucrose after contingent pairing of an intraoral infusion of $5 \%$ sucrose $(6.6$ $\mathrm{ml}$ over $6 \mathrm{~min}$ ) with different doses of $\mathrm{LiCl}[0(\bigcirc), 19(\square)$, $38(\mathbf{\Delta})$, or $76(-) \mathrm{mg} / \mathrm{kg}]$ or $0.15 \mathrm{M} \mathrm{NaCl}(12 \mathrm{ml} / \mathrm{kg})$. Individual rats were tested only once at one time point $(n=4-9)$. Intakes from Fig. 1 for the time points at 15 min, $1 \mathrm{hr}, 6 \mathrm{hr}$, and $48 \mathrm{hr}$ after $76 \mathrm{mg} / \mathrm{kg}$ were included in the analysis and data shown here. After all doses of $\mathrm{LiCl}$, rats significantly decreased intraoral intake of sucrose at $15 \mathrm{~min}$ to $3 \mathrm{hr}$ doses compared to $\mathrm{NaCl}$ treatment. After $6 \mathrm{hr}$, however, intraoral intake of sucrose was only significantly decreased after pairing with the highest dose of LiCl. (*) $P<0.005$ vs. intake after 76 $\mathrm{mg} / \mathrm{kg} ;{ }^{+} P<0.05$ vs. intake after $38 \mathrm{mg} / \mathrm{kg}$.

rats in experiment 1 rejected an intraoral infusion of $5 \%$ sucrose within $15 \mathrm{~min}$ of prior pairing of sucrose and LiCl. The rapid expression of a CTA within minutes of pairing was not caused by the acute toxic effects of $\mathrm{LiCl}$ or satiating effects of their first intraoral infusion of sucrose, because rats only rejected sucrose after contingent pairing of sucrose and LiCl. Furthermore, CTA learning can be labile, because the rats in experiment 2 that received an intraoral infusion of sucrose paired with low doses of $\mathrm{LiCl}$ rejected sucrose for at least $3 \mathrm{hr}$ after pairing, but did not reject sucrose after 6 hr. Because the intraoral intake of each rat was tested at only one time point after the pairing of sucrose and $\mathrm{LiCl}$, the decay curves constructed in experiment 2 represent forgetting of a labile, shortterm CTA.

Finally, short-term expression of a CTA persisted after ICV administration of cycloheximide, a protein synthesis inhibitor, during the pairing of sucrose and LiCl, whereas long-term expression of a CTA was blocked by cycloheximide administration. Thus CTA learning appears to be protein synthesis independent within $1 \mathrm{hr}$ after the pairing of sucrose and $\mathrm{LiCl}$, but requires protein synthesis within at least the first $6 \mathrm{hr}$ after the pairing.

It should be noted that the duration of the short-term CTA we observed is still very long compared to short-term memory in other types of learning (e.g., $1 \mathrm{hr}$ in a fear-conditioning test of transgenic mice deficient in long-term memory consolidation; Bourtchuladze et al. 1994). It remains to be determined if the period of short-term memory in CTA ( $15 \mathrm{~min}-4.5 \mathrm{hr}$ ) is mediated by a single process, or is composed of multiple phases (i.e., shortand medium-term phases) and independent processes.

There have been other reports that rats reject diets or taste solutions after pairing with toxic effects within minutes to hours, but using different experimental paradigms that do not establish a role for classical CTA learning. For example, rats decrease their ad lib intake of saccharin solutions within $1.5 \mathrm{hr}$ of radiation exposure (Carroll and Smith 1974; Smith and Roll 1967) or 15 min after nitrogen mustard injection (Garcia et al. 1972). Similarly, within hours of ad lib access to diets con-

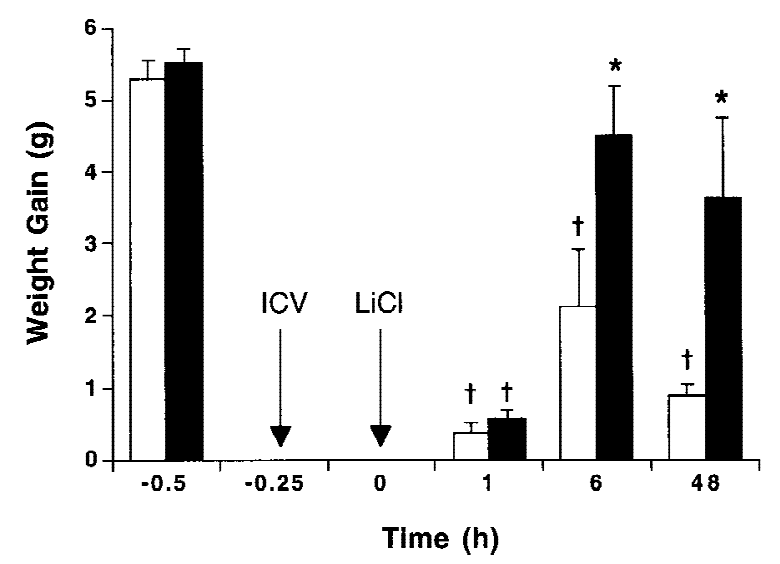

Figure 3: Protein-synthesis-independent and -dependent expression of CTA. Rats received an intraoral infusion of $5 \%$ sucrose, followed 15 min later by an ICV injection of $0.15 \mathrm{M} \mathrm{NaCl}(10 \mu \mathrm{l}$; open bars) or cycloheximide $(250 \mu \mathrm{g} / 10 \mu \mathrm{l}$; solid bars); $15 \mathrm{~min}$ after the ICV injection, all rats received $\mathrm{LiCl}(76 \mathrm{mg} / \mathrm{kg}$, i.p.). Individual rats were tested only once at one time point $(n=5-8)$. After either ICV cycloheximide or $\mathrm{NaCl}$, rats significantly decreased intraoral intake of sucrose at $1 \mathrm{hr}$ compared to their initial sucrose intake. At 6 and $48 \mathrm{hr}$, however, intraoral intake of sucrose was significantly decreased only after ICV NaCl; cycloheximide-treated rats consumed significantly more sucrose than $\mathrm{NaCl}$ treated rats, with no significant decrease compared to their initial sucrose intake. $\left(^{*}\right) P<0.05$ vs. $\mathrm{NaCl}$-treated rats; $\left({ }^{+}\right) P<0.05$ vs. sucrose intake during pairing.

$$
\begin{array}{llllllllllllllll} 
& E & A & R & N & I & N & G & \boldsymbol{Q} & M & E & M & O & R & Y \\
\mathbf{4 3} & & & & & &
\end{array}
$$


taining balanced or imbalanced proportions of essential amino acids, rats begin to avoid the imbalanced diet that induces toxic effects (Beverly et al. 1990). These studies did not discriminate, however, between the acute effects of the toxins on intake and a learned, long-delay association of taste and toxin.

Intraoral catheters have been used previously by two groups to examine short-term expression of taste learning with greater stimulus and temporal control than is provided by ad lib intake tests (Eckel and Ossenkopp 1996; Spector et al. 1988). They presented rats with brief intraoral infusions of sweet solutions after acute $\mathrm{LiCl}$ injections to demonstrate within 10 min a rapid, learned change in orofacial taste reactivity from palatable, ingestive responses to aversive, rejection responses. Unlike most CTA studies, however, their paradigm used a forward pairing of toxin with taste rather than long-delay learning; furthermore, intake was not measured. Our paradigm avoids these complications and assesses intake at arbitrary time points after long-delay CTA learning.

In addition to rapidity and lability, a short-term memory phase should also be protein synthesis independent. There is evidence that long-term CTA memory requires protein synthesis. Administration of general protein synthesis inhibitors into the lateral ventricles (Tucker and Gibbs 1976; Serova et al. 1995) or cerebral cortex (Rosenblum et al. 1993) attenuates long-term expression of CTAs. Long-term CTA has been attenuated also by inhibiting the synthesis of specific proteins with antisense oligonucleotides: c-Fos or CREB within the amygdala (Lamprecht and Dudai 1996; Lamprecht et al. 1997), and c-Fos in the brain stem after fourth-ventricular administration (Swank et al. 1996). Only a few studies, however, have evaluated the effects of protein synthesis inhibitors (Tucker and Gibbs 1979) or antisense oligonucleotides (Lamprecht et al. 1997) on the short-term expression of a CTA (i.e., $<24 \mathrm{hr}$ after acquisition).

The time course of short-term memory in CTA learning suggests that short-term expression of a CTA is protein synthesis independent. We observed CTA expression within $15 \mathrm{~min}$ of contingent pairing of sucrose and $\mathrm{LiCl}$; whereas gene transcription may begin within $15 \mathrm{~min}$, protein translation usually requires longer times. However, the time course of the transition from short-term memory to consolidation of long-term memory of CTA is consistent with protein synthesis. We observed a decay of the short-term expression of the
CTA at lower doses of $\mathrm{LiCl}$ from 4.5 to $6 \mathrm{hr}$ after acquisition. There was no decay of CTA expression at any time point after the highest dose of $\mathrm{LiCl}$. We therefore hypothesize that the transition from short- to long-term memory in CTA learning occurs within $4.5-6 \mathrm{hr}$, and that protein synthesis prior to $4.5 \mathrm{hr}$ is required to successfully consolidate CTA learning.

Our third experiment demonstrated that central administration of cycloheximide, a protein synthesis inhibitor, does in fact block long-term CTA expression but not short-term CTA expression. Although this result supports our hypothesis, several caveats must be made. Because we only tested one dose of cycloheximide at one time point, we cannot determine the precise time of protein synthesis that is critical for long-term CTA consolidation. Because the cycloheximide was administered ICV and thus delivered to much of the brain, we also cannot determine the specific sites of protein synthesis that mediate long-term CTA consolidation. Finally, because cycloheximide is a general inhibitor of protein translation, we cannot determine the specific proteins that are sufficient and necessary for long-term CTA consolidation. Nonetheless, the general inhibition of protein synthesis throughout the brain did cause nearly complete reversal of long-term CTA expression without attenuating short-term CTA expression and thus provides a useful starting point for future experiments.

Over the last 30 years, advances in biochemistry, molecular biology, and neurobiology have implicated specific neural and molecular substrates of short-term and long-term memory in mammalian learning. At the anatomical level, for example, damage to the hippocampus and adjacent cortex in primates causes long-term amnesia without affecting short-term cognitive memory (Alvarez et al. 1994) . At the molecular level, transgenic mice deficient in cAMP-responsive element binding protein (CREB) have impaired long-term memory, but normal short-term memory in tasks such as fearconditioning, spatial learning, and social learning of food preference (Bourtchuladze et al. 1994; Kogan et al. 1996). [The recent results of Lamprecht et al. (1997) suggest that CREB is essential for longterm memory in CTA as well.] Also, transgenic mice deficient in $\alpha$-calcium calmodulin kinase II or synapsin II have impairments in both short- and long-term memory in fear-conditioning or spatial learning (Silva et al. 1996).

These anatomical and molecular paradigms for dissociating short- and long-term memory have not

$$
\begin{array}{llllllllllllllll}
L & E & A & R & N & I & N & G & \begin{array}{l}
\boldsymbol{Z} \\
\mathbf{4} 4
\end{array} & M & E & M & O & R & Y
\end{array}
$$


been applied to short- and long-term memory in CTA learning. To a large extent, an emphasis on the unique long-term temporal properties of CTA learning has led to a neglect of the short-term characteristics of CTA learning. Furthermore, the analysis of CTA learning has lacked experimental paradigms to analyze short- and long-term phases of CTA memory. Thus, there have been few examples of CTA amnesia or identifications of molecular substrates of short-term CTA vs. long-term CTA. The demonstration of rapid, labile, and protein-synthesis-independent short-term expression of a CTA distinct from long-term expression will permit the testing of modern models of short- and long-term plasticity in CTA learning.

\section{Acknowledgments}

We thank Gerard P. Smith and Paul Rushing for critical readings of the manuscript, and Rahel Nardos for technical assistance. This work was supported by National Institutes of Health grant DC03198.

The publication costs of this article were defrayed in part by payment of page charges. This article must therefore be hereby marked "advertisement" in accordance with 18 USC section 1734 solely to indicate this fact.

\section{References}

Alvarez, P., S. Zola-Morgan, and L.R. Squire. 1994. The animal model of human amnesia: Long-term memory impaired and short-term memory intact. Proc. Natl. Acad. Sci. 91: 5637-5641.

Beverly, J.L., D.W. Gietzen, and Q.R. Rogers. 1990. Effect of dietary limiting amino acid in prepyriform cortex on meal patterns. Am. J. Physiol. 259: R716-R723.

Bourtchuladze, R., B. Frenguelli, J. Blendy, D. Cioffi, G. Schütz, and A. Silva. 1994. Deficient long-term memory in mice with a targeted mutation of the CAMP-responsive element binding protein. Cell 79: 59-68.

Carroll, M.E. and J.C. Smith. 1974. Time course of radiation-induced taste aversion conditioning. Physiol. Behav. 13: 809-812.

Eckel, L.A. and K.-P. Ossenkopp. 1996. Area postrema mediates the formation of rapid, conditioned palatability shifts in lithium-treated rats. Behav. Neurosci. 110: 202-212.

Garcia, J. and R.A. Koelling. 1967. A comparison of aversions induced by X-rays, toxins, and drugs in the rat. Radiat. Res. Supl. 7: 439-450.

Garcia, J. and F.R. Ervin. 1968. Gustatory-visceral and telereceptor-cutaneous conditioning-Adaptation in internal and external milieus. Comm. Behav. Biol. 1: A389-415.

Garcia, J., F.R. Ervin, and R.A. Koelling. 1966. Learning with prolonged delay of reinforcement. Psychon. Sci. 5: 121-122.
Garcia, J., B.K. McGowan, and K.F. Green. 1972. Biological Constraints on Conditioning. In Classical Conditioning II: Current Research and Theory (ed. A.H. Black and W.F. Prokasy), pp. 21-43, Appleton-Century Crofts, New York, NY.

Grill, H. J. and K.C. Berridge. 1985. Taste reactivity as a measure of the neural control of palatability. In Progress in psychobiology and physiological psychology (ed. J.M. Sprague and A.N. Epstein), pp. 1-61, Academic Press, New York, NY.

Houpt, T.A., J.M. Philopena, T.C. Wessel, T.H. Joh, and G.P. Smith. 1994. Increased c-Fos expression in the rat nucleus of the solitary tract after conditioned taste aversion formation. Neurosci. Lett. 172: 1-5.

Houpt, T.A., J.M. Philopena, T.H. Joh, and G.P. Smith. 1996. c-Fos induction in the rat nucleus of the solitary tract correlates with the retention and forgetting of a conditioned taste aversion. Learn. \& Mem. 3: 25-30.

Houpt, T.A., E.S. Corp, and R.A. Berlin. 1998. Intracerebroventricular angiotensin II increases intraoral intake of water in rats. Peptides 19: 171-173.

Kogan, J.H., P.W. Frankland, J.A. Blendy, J. Coblentz, Z. Marowitz, G. Schütz, and A.J. Silva. 1997. Spaced training induces normal long-term memory in CREB mutant mice. Curr. Biol. 7: 1-11.

Lamprecht, R. and Y. Dudai. 1996. Transient expression of C-Fos in rat amygdala during training is required for encoding conditioned taste aversion memory. Learn. \& Mem. 3: 31-41.

Lamprecht, R., S. Hazvi, and Y. Dudai. 1997. cAMP response element-binding protein in the amygdala is required for longbut not short-term conditioned taste aversion memory. J. Neurosci. 17: 8443-8450.

Nachman, M. and J.H. Ashe. 1973. Learned taste aversions in rats as a function of dosage, concentration, and route of administration of LiCl. Physiol. Behav. 10: 73-78.

Rosenblum, K., N. Meiri, and Y. Dudai. 1993. Taste memory: The role of protein synthesis in gustatory cortex. Behav. Neural Biol. 59: 49-56.

Schafe, G.E., S.I. Sollars, and I.L. Bernstein. 1995. The CS-US interval and taste aversion learning: A brief look. Behav. Neurosci. 109: 799-802.

Serova, O.N., N.A. Solov'eva, L.V. Lagutina, and M.F. Obukhova. 1995. The formation of taste aversion and preference under conditions of protein synthesis inhibition in rats [Russian]. Zh. Vyss. Nerv. Deyat. Im. I.P. Pavlova 45: 742-747.

Silva, A.J., T.W. Rosahl, P.F. Chapman, Z. Marowitz, E. Friedman, P.W. Frankland, V. Cestari, D. Cioffi, T.C. Südhof, and R. Bourtchuladze. 1996. Impaired learning in mice with abnormal short-lived plasticity. Curr. Biol. 6: 1509-1518.

Smith, J.C. and D.L. Roll. 1967. Trace conditioning with X-rays as an aversive stimulus. Psychon. Sci. 9: 11.

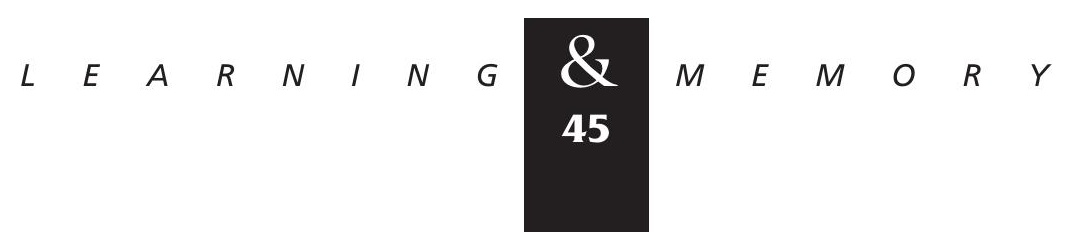




\section{Houpt and Berlin}

Spector, A.C., P. Breslin, and H.J. Grill. 1988. Taste reactivity as a dependent measure of the rapid formation of conditioned taste aversion: A tool for the neural analysis of taste-visceral associations. Behav. Neurosci. 102: 942-952.

Swank, M.W., A.E. Ellis, and B.N. Chochran. 1996. c-Fos antisense blocks acquisition and extinction of conditioned taste aversion in mice. NeuroReport 7: 1866-1870.

Tucker, A. and M. Gibbs. 1976. Cycloheximide-induced amnesia for taste aversion memory in rats. Pharmacol. Biochem. Behav. 4: 181-184.

Tucker, A.R. and M.E. Gibbs. 1979. Saccharin aversion memory in rats: Inhibition of cycloheximide-resistant memory by ouabain. Physiol. Behav. 23: 341-346.

Received August 14, 1998; accepted in revised form January 22, 1999. 


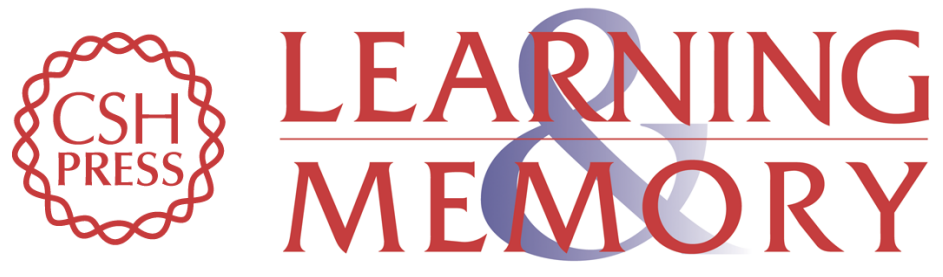

\section{Rapid, Labile, and Protein Synthesis- Independent Short-Term Memory in Conditioned Taste Aversion}

Thomas A. Houpt and RoseAnn Berlin

Learn. Mem. 1999, 6:

Access the most recent version at doi:10.1101/lm.6.1.37

References This article cites 20 articles, 4 of which can be accessed free at: http://learnmem.cshlp.org/content/6/1/37.full.htmI\#ref-list-1

License

Email Alerting Receive free email alerts when new articles cite this article - sign up in the box at the Service top right corner of the article or click here. 